Man and Nature

L'homme et la nature

\title{
Writing Boswell: Form, Text, and Identity in the London Journal
}

\section{Lisa M. Zeitz}

Volume 10, 1991

URI : https://id.erudit.org/iderudit/1012637ar

DOI : https://doi.org/10.7202/1012637ar

Aller au sommaire du numéro

Éditeur(s)

Canadian Society for Eighteenth-Century Studies / Société canadienne d'étude du dix-huitième siècle

ISSN

0824-3298 (imprimé)

1927-8810 (numérique)

Découvrir la revue

Citer cet article

Zeitz, L. M. (1991). Writing Boswell: Form, Text, and Identity in the London Journal. Man and Nature / L'homme et la nature, 10, 227-238. https://doi.org/10.7202/1012637ar

Copyright (c) Canadian Society for Eighteenth-Century Studies / Sociéte canadienne d'étude du dix-huitième siècle, 1991
Ce document est protégé par la loi sur le droit d'auteur. L'utilisation des services d'Érudit (y compris la reproduction) est assujettie à sa politique d'utilisation que vous pouvez consulter en ligne.

https://apropos.erudit.org/fr/usagers/politique-dutilisation/ 


\section{Writing Boswell: Form, Text, and Identity in the London Journal}

James Boswell's 'favourite subject' - himself - has in recent years also become something of a favourite subject for literary scholars and theorists. The reasons are not far to seek. First, pioneering critics such as Patricia Spacks and Elizabeth Bruss have provided both a theoretical framework and the example of a practical criticism for the discussion of formal autobiography and other types of 'self-writing' (of which diaries are one example). Secondly, Boswell's London Journal offers particular advantages: as a journal covering less than a year in the life of this most self-conscious of eighteenth-century diarists, Boswell's work raises a number of important formal and theoretical questions - and does so in such a transparent manner that it in effect identifies the central issues that must be addressed in any analysis of self-writing.

One of those central issues is the 'doubleness' of autobiographical expression. As Paul Jay (and virtually everyone else who considers self-writing) observes, 'in no other kind of literary work is the relation between the self-as-author, and the self-as-subject... so problematical. ${ }^{2}$ Any interpretation of an autobiographical document must address the relationship between the acting ' $\mathrm{I}$ ' (Boswell the man, the subject) and the writing ' $\mathrm{I}$ ' (Boswell the journalist, the author). Nowhere is the imaginative power of the 'writing I' to create the 'acting I' clearer than in the London Journal. Identity is not born, but made, as Boswell himself soon realizes: within a week of commencing his daily record, he writes, 'I have discovered that we may be in some degree whatever character we choose' (21 November 1762, p.47). ${ }^{3}$

Boswell's 'self-imaging, ${ }^{4}$ his role-playing, and the extraordinary malleability of the public images and roles that he presents to the world have been the focus of much critical writing about the London Journal. ${ }^{5}$ And rightly so. Flamboyantly staging a succession of theatrical scenes, Boswell is variously Macheath, Mr. Spectator, West Digges, a 'true gentleman,' a man of fashion, a 'Man of Pleasure,' a blackguard, and the list goes on. So prevalent is this dramatic strategy that one commentator has described the journals as 'equivalent to a remarkable series of actor's notebooks. ${ }^{6}$ It is in the role-playing, of course, that we most clearly see 
Boswell constructing a series of shifting identities, trying on characters the way other people try on clothes. Predictably, this obsessive assumption of roles ultimately ends in failure - the authentic self (if there is such a thing) is smothered under the weight of costumes and stage props. It would be several years before Boswell could finally record his recognition that 'I must be Mr. Boswell of Auchinleck, and no other. Let me make him as perfect as possible' (9 August 1764).?

The journal that records Boswell's inner struggle is itself, of course, an attempt to recognize and stabilize identity. The young journalist hopes that his efforts will culminate in self-knowledge: The ancient philosopher certainly gave a wise counsel when he said, "Know thyself." For surely this knowledge is of all the most important' ('Introduction,' p.39). Boswell's effort to attain knowledge of his identity is my subject here, but I wish to take an approach that is somewhat different from those I have already described. Rather than focusing primarily on the substance of the journal, I shall instead centre my discussion on Boswell's attitude towards his journal, and in particular, on the relationship between text and identity. How is the issue of the 'discovery' or the construction of a personal identity related to the journalist's view of his written record? Any sense of his identity that Boswell may ultimately possess is derived, after all, from this text; through the journal his character is both discovered and devised. In fact, a close reading reveals that the journal itself becomes an image of Boswell that then 'confirms' the identity he has 'written' (i.e. constructed) in its pages.

That Boswell himself was fully aware of the potential of the journal to make and then reflect identity is clear from an entry in his earlier 'Journal of My Jaunt, Harvest 1762.' In what reads almost as a prolegomenon to the London Journal, Boswell reports a conversation he has had with Lord Kames about his desire to be an author; he describes the rewards of writing, thus:

It is making another self which can be present in many places and is not subject to the inconstancies of passion, which the man himself is. I told him [Lord Kames] that I should like much to be distinguished in that way: that I was sure that I had genius... but was at a loss for something to say, and, when I set myself seriously to think of writing, that I wanted a subject. ${ }^{8}$

Of course, although it is unknown to him, it is clear that Boswell has found his subject - himself. ${ }^{9}$ It is also apparent that, although one assumes that Boswell is thinking primarily of fiction here, he is fully cognizant of the powerful relationship between writing and bringing character into being. One of the attractions of 'making another self,' he 
suggests, is that the other self is not subject to the inconstancies of passion' - something with which Boswell is constantly struggling. Writing is 'making another self,' and the London Journal shows the diarist forging that self (often through the use of literary or novelistic strategies) and naming it Boswell.

Before looking at particular examples of Boswell's self-writing it may be helpful to consider those features which are specifically 'journalistic.' A journal obviously represents a very different kind of self-writing from that of the formal autobiography. It is not the product of an act of recovery or reconstruction so much as it is a process of writing. Unlike formal autobiography, a journal is focused on the immediate present and the uncertain future - the day or the week rather than the life. As the act of journal-keeping continues, however, it fixes the writer in time, day by day, and becomes a kind of written memory, a textual artefact of identity. ${ }^{10}$ Any 'plan' or 'method' or 'form' that it exhibits (the terms are Boswell's) must be apparent from the immediate record because the journalist is recording events very soon after they have happened (within a week, in Boswell's case); the author of a formal autobiography, on the other hand, might look back years later, and select a narrative sequence or pattern of events that illustrated a larger design, apprehended or constructed from the details of a lifetime. Boswell's concern that his journal provide some evidence of 'form' and 'plan' - and it is an obsessive concern - is simply another way of expressing his hope that his life will exhibit some kind of coherence or stability. There is an obvious parallel between how Boswell attempts to impose form on his journal and how he attempts to impose a similar kind of order and stability on his life. ${ }^{11}$ He looks for form in the journal as 'evidence' of order in his life - but the form he finds, he has put there.

James Boswell, age 22, journeys to London in search of a commission in the Footguards. A military officer is presumed to be both a true gentleman and a disciplined and stable 'man of form' - the sort of man who might well keep a regular and objective record of his daily activities:

I have... determined to keep a daily journal in which I shall set down my various sentiments and my various conduct, which will be not only useful but very agreeable. It will give me a habit of application and improve me in expression; and knowing that I am to record my transactions will make me more careful to do well. Or if I should go wrong, it will assist me in resolutions of doing better. ('Introduction,' p.39)

In these early days, of course, Boswell is full of hope that his journal will reflect a consistent character and that when it does not, it will act as a kind 
of moral prod for improvement. What Boswell, in search of a commission, wants to find in himself (in addition to a lively variety of conduct and 'sentiments') is a love of form, and the language of this first description of his journal-keeping demonstrates this desire: notice the verbs, for example - 'I have determined,' 'I shall set down'; the adjectives, 'careful' and 'useful'; and the nouns describing the effects of the activity - 'habit of application,' 'resolutions.' The fact that he is disciplined enough to keep a journal is the first 'evidence' of his fitness for a life of independenceor at least of his fitness to make his 'choice of life' (as problematica task for Boswell, of course, as it was for Johnson's Rasselas).

The letters to John Johnston that accompanied each weekly packet of the journal contain obsessive page counts, careful instructions for the journal's preservation and safe-keeping, and comments indicating Boswell's own view of his journal and what it 'represents.' If Johnston reads the journal in the way that Boswell clearly directs him to, he will conclude that the sheer determination required to adhere to this programme of writing is testimony to Boswell's steadiness, perseverance, and 'regular' conduct. The letter to Johnston on 11 January 1763 is typical: 'I begin to think myself obliged to furnish you with Six Sheets of Journal every week. Indeed the task . . is a good one . . . I think I might venture to challenge all the young men of life and spirit about town at steadiness and exact perseverance. ${ }^{12}$ Boswell includes himself among 'all the young men of life and spirit about town,' but he distinguishes himself as someone who adds to that youthful exuberance the qualities of 'steadiness and exact perseverance.' On 29 January 1763, he reminds Johnston that he is 'most scrupulously regular in sending my packets' (p.42); such 'constant care' (p.43) merits repetition of the observation made a month earlier: 'I could not help thinking that such uncommon regularity and attention in a young man of life and spirit, amidst all the hurry and gayety of the Metropolis, was much to be admired' (8 February 1763, p.43). Both the journal itself and the 'exact' correspondence with Johnston 'testify that I am a man of exceeding Accuracy' (12 July 1763, p.87): 'My attention to stated rules and forms is great' (1 March 1763, p.53). Even the regular act of simply posting the journal helps Boswell to construct that favourite image of himself as a 'man of form':

MY DEAR JOHNSTON: I am a man whom nature has endowed with a love of forms and Ceremonies. When once I fix on a time when, and a method how any thing is to be done, I observe my plan as religiously as a Turk does the prescriptions of his Prophet....

As an instance of this my attachment to forms, Tuesday's is the Post by which I 
fixed to send off my weekly packet of Journal, and I dare affirm that during the time that I have been in London, I have never once sent it by any other Post. (2 August 1763, pp.104-105)

Here the mere act of writing and posting the journal (regardless of what evidence of inconsistency and vacillation the entries may contain) provides a verifiable 'instance' of Boswell's 'attachment to forms.'

Yet although he promises to 'regularly [my emphasis] record the business or rather the pleasure of every day,' he also admits that he will omit things: 'I shall be upon my guard to mention nothing that can do harm. Truth shall ever be observed, and these things (if there should be any such) that require the gloss of falsehood shall be passed by in silence' (p.40). Boswell clearly wants his journal to provide evidence of his being a 'man of form,' yet he is already hedging his bets.

Perhaps the clearest example that illustrates the way in which a textual order is devised and then 'discovered' as a 'personal' order is the 'Dialogue at Child's.' In the journal entry for Saturday 11 December 1762 , Boswell records his visit to Child's Coffee-house, and suggests that reports of subsequent visits will become a regular feature of his journal: 'I shall hereafter for the sake of neatness throw our conversation into my journal in the form of a dialogue. So that every Saturday this my Journal shall be adorned with A DIALOGUE AT CHILD'S' (p.74). The implicit imaging of the journal as having the regularity of a periodical paper 'written' from a coffee house is made explicit at the end of this first dialogue:

The Spectator mentions his being seen at Child's, which makes me have an affection for it. I think myself like him, and am serenely happy there. There is something to me very agreeable in having my time laid out in some method, such as every Saturday going to Child's. (p.76)

Boswell wants to give 'some method' to his life, to establish some pattern in the way in which his time is 'laid out,' and so he settles upon the inclusion of a regular literary feature - a 'Saturday paper' - within the journal. In doing so, he is responding to an observation made by his friend John Johnston (who is, of course, the specific 'audience' for the journal). On December 1, less than two weeks before the dialogues begin, Boswell had written: 
I remember my friend Johnston told me one day after my return from London [the first trip] that I had turned out different from what he imagined, as he thought I would resemble Mr. Addison. I laughed, and threw out some loud sally of humour, but the observation struck deep ... Now, when my father at last put me into an independent situation, I felt my mind regain its native dignity. I felt strong dispositions to be a Mr. Addison. (p.62)

In part, the integration of a 'Spectatorial' report from a coffee house is an attempt to convince both John Johnston and James Boswell of the progress the journalist is making towards attaining a character of dignity and 'method.' Yet, in recording the disposition 'to be a Mr. Addison' first, and discovering the 'evidence' of the dialogue later, Boswell is really illustrating how the journal works to 'confirm' an identity constructed in its very pages.

In the next Saturday entry, 18 December 1762, Boswell admits that having arrived at the coffee house a little late, he has little or nothing 'worth setting down. However, as I am a man who loves forms Imy emphasis], I shall always continue to present (such as it is) my Saturday's DIALOGUE AT CHILD'S' (p.94). The following Saturday is Christmas Day and after attending the service at St. Paul's, Boswell heads next door. 'I then went to Child's, where little was passing. However, here goes the form of a DIALOGUE AT CHILD'S' (pp.104-05). Boswell begins the New Year of 1763 with the continuation of the form of the journal. 'Saturday 1 January. DIALOGUE AT CHILD'S' (p.115). There is no dialogue for January 8; by the time Boswell arrived at the coffee house there was no one left, 'so this day must want that garnish, as I am resolved to adhere strictly to fair truth in this my journal' (p.128). What we have instead of a dialogue, however, is far more significant.

We have already seen how the 'Dialogue at Child's' seems, to Boswell, to link him with Mr. Spectator (or Mr. Addison). Now, Boswell construes what he calls his 'regular plan' (p.128) as 'proof' of his qualification for a commission in the Guards. Order in the journal is easily read as order in the self: 'Indeed it vexes me a little to be put out of my regular plan ....I do think my love of form for its own sake is an excellent qualification for a gentleman of the Army, where there is such a deal of form and variety of attitude' (p.128). The journal 'confirms' Boswell's construction of himself as a 'man of form' - 'an excellent qualification for a gentleman of the Army.'

Of course, reality is always gaining on young Jamie. On Saturday 22 January 1763 , we miss the weekly dialogue and learn that our man of form has been kept from 'comfortable Child's' by a 'dreadful' 'distemper' (p.165). What he had earlier noticed as 'a little heat in the members 
of my body sacred to Cupid' (p.149) has been followed by a painful recognition: 'Too, too plain was Signor Gonorrhoea' (p.155). The wish to be perceived as 'a man of form' is so closely connected with the textual order of the journal (specifically, the 'Dialogue at Child's'), that on the day following, Boswell disappointedly reflects, 'I considered the Guards as a most improper scene of life for me' (p.165). While far from being his final word on the subject (or perhaps one should say, his final vacillation), the dynamic relationship between text and identity that we have been examining here is indicative of the way in which the journal functions for Boswell.

Having discussed the particular example of Boswell's devising and subsequent discovery of his 'love of form,' I would like to suggest how I think this example may be used to talk more theoretically about how a journal differs from formal autobiography and why Boswell's London Journal seems to provide its own commentary on itself. Had we been reading a formal autobiography of recollection - let us imagine Boswell writing 20 years after the period covered by the journal - we might have confronted an author who simply 'remembered' his great 'love of form' as a young man. The journal, on the other hand, shows him in the process of creating or constructing that image of order - an image that might later be 'recollected' as fact. What is fascinating about this journal as a literary work is that it shows the linguistic and literary structuring of an identity that might later be recalled as a 'given.'

That Boswell thought of the journal as a form that allowed for the adjustment and restructuring of one's identity is clear from his use of the image of the mirror to describe journal-writing. In the Life of Johnson, he observes, 'as a lady adjusts her dress before a mirror, a man adjusts his character by looking at his journal. ${ }^{13}$ For Boswell, the journal is a mirror of character - it reflects an image that the journalist can adjust. After the adjustment to character has been made, the 'mirror' of the journal reflects the new image. The inclusion of a concern with form represents just that kind of adjustment of identity that Boswell seeks. Once it is recorded in the journal, once the writer has placed the image of 'a Mr. Addison' (or a Mr. Digges, or a Macheath) before the mirror, the mirror, of course, reflects it back, 'fixing' it - at least until the next journal entry reflects another image.

It is a testimony to Boswell's genuine determination to 'know himself' that he candidly acknowledges what the most casual reader of the journal would recognize - that the picture in the mirror is often blurred and inconsistent: from the entry for 25 February 1763, 'if I should suddenly relinquish my favourite schemes [of being a Guardsman], I should deservedly be considered as a man of no stability but inconstant and wavering with every breath'; 'I was somewhat uneasy at the con- 
sideration of my indetermined state of mind, which argues a degree of imbecility' (p.202). From the entry for 27 February 1763, 'O why can I not always preserve my inclinations as constant and as warm?'; 'I am vexed at such a distempered suggestion's being inserted in my journal, which I wished to contain a consistent picture of a young fellow eagerly pushing through life' (pp.205-06). What Boswell wants to value in himself is stability, constancy, strength of purpose, and energetic determination; the ideal of the charming 'man of form' is related not only to the dashing figure of a member of the Household Guard, but also to what Boswell describes as 'dignity of character':

I was now upon a plan of studying polite reserved behaviour, which is the only way to keep up dignity of character. And as I have a good share of pride, which I think is very proper and even noble, I am ... unsatisfied if I do not feel myself something of a superior animal. (1 December 1762, p.61)

A similar valuation of 'dignity of character' may be found in David Hume's discussion of 'qualities immediately agreeable to ourselves' in An Inquiry Concerning the Principles of Morals (1751). 'Who is not struck,' Hume asks, 'with any signal instance of greatness of mind or dignity of character ... and with that noble pride and spirit which arise from conscious virtue $?^{\prime 14}$ The great philosopher (with whom, as he records in the London Journal, Boswell tried to construct a correspondence because, as he explained, 'the correspondence of distinguished men ... gives a man a dignity that is very desirable' [p.194]) suggests the consequences of an absence of such dignity: 'We never excuse the absolute want of spirit and dignity of character, or a proper sense of what is due to one's self in society and the common intercourse of life.' A man who 'degrade[s] himself by intimacies and familiarities with undeserving inferiors' is 'mean,' and does not recognize that 'a certain degree of generous pride or self-value is so requisite that the absence of it in the mind displeases ....'15

What both Hume and Boswell describe as 'dignity of character' seems closest to what we might term a sense of self-worth, or self-respect, or 'personal integrity' - the kind of integrity that would flow from a harmonious and 'spirited' self. Reflecting upon an especially successful social engagement towards the end of the London Journal (13 May 1763), Boswell writes: 'I was rational and composed, yet lively and entertaining ... Could I but fix myself in such a character and preserve it uniformly, I should be exceedingly happy. I hope to do so and to attain a constancy and dignity without which I can never be satisfied . . . my natural character is that of dignity' (p.258). A week or so later, in his memorandum 
for 21 May 1763, Boswell commands himself to 'acquire dignity' (p.265). The textual confirmation of this determination comes in the journal entry for that day through the advice offered by Temple (whom Boswell had, of course, sought out): 'Temple ... talked to me seriously of getting out of a course of dissipation and rattling and of acquiring regularity and reserve, in order to attain dignity of character and happiness' (p.265). But how exactly can the desire to 'acquir[e] regularity and reserve' be transformed into attainment? How is 'dignity of character' and the 'happiness' that accompanies it to be 'fixed'?

To answer this question we must return to what the journal itself represents to Boswell. Ultimately, the only meaningful 'constant' the young writer can perceive in his life is the activity of writing; as has already been indicated, the journal itself is an obvious attempt to stabilize an identity that, outside its pages, is constantly shifting. For Boswell, identity becomes synonymous with the text; he does not know himself outside it. In all those pages is Boswell; the journal is what most completely 'contains' him in all his uncertainties and vacillations. The role that ultimately 'fits' Boswell is the role of Boswell the journalist. It is, then, with great satisfaction that Boswell records, on 16 July 1763, Samuel Johnson's advice to him 'to keep a journal ... fair and undisguised' (p.305). Boswell's exultant language describing his feelings concerning Johnson's approval of what he has spent a large portion of his time doing, is telling indeed: 'O my journal! art thou not highly dignified [my emphasis]? Shalt thou not flourish tenfold?' (p.305). For 'my journal' we may surely read ' $m e^{\prime}$; by 'dignifying' the journal, Johnson (in Boswell's phrasing) 'dignifies' the life it contains, that is, accords Boswell himself an integrity of identity - a certain degree of 'self-value.' In describing his journal as 'highly dignified,' Boswell constructs an image of Johnson recognizing and accepting his young friend as he is - indeed, according Boswell 'a proper sense of what is due to' him. If the journal is valued and respected by Johnson, so, too, is Boswell. Of course, Johnson does not know the Boswell of the text. The 'Boswell' that the journal exhibits can exist only in its pages - as much an imaginative construct as any fictional protagonist. ${ }^{16}$

The journal's character as a literary construction is by now a critical commonplace; its 'essentially novelistic' shape is achieved, Patricia Spacks suggests, by the diarist's unremitting effort to convert his life into a work of literature as he lived it. ${ }^{17}$ Inconsistencies and contradictions are subsumed within the larger literary patterns of the romance or novel: 'Let me consider that the hero of a romance or novel must not go uniformly along in bliss, but the story must be chequered with bad fortune. Aeneas met with many disasters in his voyage to Italy, and must not Boswell have his rubs?' (27 February 1763, p.206). Among the 
techniques Boswell uses to achieve this design are the recollection and recasting of himself in specific scenes from popular plays (like Hamlet and Farquhar's The Recruiting Officer) ${ }_{i}^{18}$ the use of repeated patterns of imagery; ${ }^{19}$ and the creation of a narrative pattern. ${ }^{20}$ One thinks, for example, of the structural parallels of the staged departure scenes - the ritual farewell to Edinburgh at the beginning of the journey (15 November 1762), and the ceremonial leave-taking from London at the end (31 July 1763) - or of the paired prospect views of London that stand in pointed contrast with each other. ${ }^{21}$ The importance of literary form and the creation of repeated structural patterns is further evidence of Boswell's interest in constructing a journal that 'reveals' him to be 'a man of form.' All of the different roles and postures, including the many literary ones, may be subsumed under this wider personal imperative. Boswell's literary genius manifests itself in the author's ability to depict himself as a man of literary form. ${ }^{22}$

Although it cannot be denied that Boswell is frequently disturbed by his chequered progress, in the end he must accept himself for what he is and it is the written Boswell whom he acknowledges as his own: 'But I cannot find fault with this my journal' (25 May 1763, p.269). Boswell treasures his journal as in some sense his substantial self; as Patricia Spacks has suggested, the forms of both the novel and the autobiography save identity from pure subjectivity by converting human beings into objects, 'pages with words on them: illusions of consistent substantiality.' ${ }^{23}$

In 'An Autobiographical Essay,' Jorge Luis Borges puts forward an interesting paradigm: 'I am told of a man who sets out to make a picture of the universe. After many years, he has covered a blank wall with images ... only to find out at the moment of death that he has drawn a likeness of his own face. ${ }^{24}$ The 'universal,' it turns out, is autobiographical. But what about the man who sets out to make a picture of himself? It may be suggestive to shift and reverse this image somewhat in thinking about what we have in the London Journal. I do not want to grant a greater significance to this text than it merits, nor do I wish to accord it special priority, preeminence, or pride of place in the literature of self-writing. But I do think it may be fair to say that Boswell sets out to make a picture of himself, and in the process, draws a likeness of the form of every attempt at self-expression.

\section{LISA M. ZEITZ}

University of Western Ontario 


\section{Notes}

1 The discussions contained in Patricia Meyer Spacks' Imagining a Self: Autobiography and Novel in Eighteenth-Century England (Cambridge: Harvard Univ. Press, 1976), and Elizabeth W. Bruss' Autobiographical Acts: The Changing Situation of a Literary Genre (Baltimore: Johns Hopkins Univ. Press, 1976) offer the most illuminating commentary available on Boswell's journals.

2 Paul Jay, 'Being in the Text: Autobiography and the Problem of Subject,' MLN 97 (1982): 1045. Among the earliest discussions of Boswell's 'double consciousness of himself' is Bertrand H. Bronson's famous essay of 1944, 'Boswell's Boswell'; see Johnson Agonistes and Other Essays (Berkeley: Univ. of California Press, 1965). For a suggestive recent discussion of the 'double character' of first-person narration in fictive autobiographies, see Marie-Paul Laden, Self-Imitation in the 18th-Century Novel (Princeton: Princeton Univ. Press, 1987).

3 All references are to the Yale edition of James Boswell's private papers; Boswell's London Journal, 1762-1763, ed. Frederick A. Pottle (New York: McGraw-Hill, 1950). Date and page references will follow citations in the text.

4 The term is Bruss'; see her introduction to Autobiographical Acts.

5 In addition to the works already cited, see also A.J. Tillinghast, 'Boswell Playing a Part,' Renaissance and Modern Studies 9 (1965): 86-97, and Donald Kay, 'Boswell in the Green-Room: Dramatic Method in the London Journal, 1762-1763,' PQ 57 (1978): 195-212. Rufus Reiberg identifies a similar 'dramatic mode' in Boswell's correspondence, in his essay, 'James Boswell's Personal Correspondence: The Dramatized Quest for Identity,' in The Familiar Letter in the Eighteenth Century, ed. Howard Anderson et al. (Lawrence: Univ. of Kansas Press, 1966): 'Boswell's highly developed sense of the theatrical leads him to define himself in his letters as an actor playing various roles on a stage that he himself sets variously for rhapsodic declamation, for pastoral romance, for comedy of manners, and for heroic drama' (p.253).

6 The commentator is David W. Tarbet; see his very helpful and knowledgeable introduction to Boswell's A View of the Edinburgh Theatre During the Summer Season, 1759, A.R.S. \#179 (Los Angeles: William Andrews Clark Memorial Library, 1976), p.viii.

7 Cited by John N. Morris in Versions of the Self: Studies in English Autobiography from John Bunyan to John Stuart Mill (New York: Basic Books, 1966), p.194.

8 Cited by Frederick A. Pottle, James Boswell: The Earlier Years, 1740-1769 (New York: McGraw-Hill, 1966), p.94.

9 Pottle makes this point on p.94 (J.B.: The Earlier Years).

10 As John Morris suggests, the journalizing process is an attempt to arrest passing moments and 'to substitute something like permanence' (Versions, p.193).

11 Of course, Boswell's desire for stability does not exclude his incorporation of such other highly desirable personal qualities as liveliness, wit, gaiety, and imagination. For a reading with a very different emphasis from my own, see Ronald Primeau, 'Boswell's "Romantic Imagination" in the London Journal,' PLL 9 (1973):15-27.

12 The Correspondence of James Boswell and John Johnston of Grange, ed. Ralph S. Walker (London: Heinemann, 1966), pp.37-38. Further references are to this edition and will follow citations in the text. 
13 Cited by Donald and Carol McGinnis Kay in 'The Face in the Mirror of Boswell's London Journal,' NM 83 (1982): 201.

14 David Hume, An Inquiry Concerning the Principles of Morals, ed. Charles W. Hendel (New York: Liberal Arts Press, 1957), p.75.

15 Hume, p.77.

16 As Robert $\mathrm{H}$. Bell puts it, in his very interesting essay 'Boswell's Notes Toward a Supreme Fiction: From London Journal to Life of Johnson,' MLQ 38 (1977): 132-48, the London Journal 'comprises notes toward the supreme fiction of [Boswell's] own reliable authority' (138).

17 Spacks, p.254. See also Martin Price's brief but incisive comments on Boswell as a 'deliberate artist' in To the Palace of Wisdom: Studies in Order and Energy from Dryden to Blake (Carbondale: Southern Illinois Univ. Press, 1964), p.344.

18 Paul Fussell's essay, 'The Force of Literary Memory in Boswell's London Journal,' SEL 2 (1962): 351-57, remains essential reading on Boswell's use of literary models. See also Richard J. Jaarsma, 'Boswell the Novelist: Structural Rhythm in the London Journal,' North Dakota Quarterly 34 (1966): 51-60.

19 See Allan Ingram, Boswell's Creative Gloom: A Study of Imagery and Melancholy in the Writings of James Boswell (London: Macmillan, 1982), especially chapter 2.

20 See Frederick S. Kiley's succinct treatment of narrative design in 'Boswell's Literary Art in the London Journal,' College English 23 (1962): 629-32.

21 The optimistic experience of 19 November 1762, when Boswell, 'all life and joy' (p.43), views 'a certain prospect of happy futurity' (p.44), is replaced by the somewhat dour report of 19 July 1763 that the 'immense prospect of London ... gave me no great idea' (p.310). It is worth noting that the view from St. Paul's was actually taken on the 12th of July; in his letter to Johnston on that day, Boswell reports that 'this forenoon' 'I have been upon the top of St. Paul's' (Correspondence, p.88). It seems to me not completely improbable that Boswell defers the report in order to achieve parallelism of form (19 November and 19 July).

22 Boswell also writes himself as a clever stylist: 'How easily and cleverly do I write just now! I am really pleased with myself; words come skipping to me like lambs upon Moffat Hill; and I turn my periods smoothly and imperceptibly like a skilful wheelwright turning tops in a turning-loom. There's fancy! There's simile! In short, I am at present a genius' (9 February 1763, p.187).

23 Spacks, Imagining a Self, p.22. As Fredric V. Bogel writes, Boswell's 'real goal is an unattainable consciousness of depth, complexity, and substantiality of identity' (p.39); see his stimulating book, Literature and Insubstantiality in Later Eighteenth-Century England (Princeton: Princeton Univ. Press, 1984), especially chapters 2 and 5.

24 Cited by Bruss, p.25. 